\title{
ARTISTIC FEATURES OF DISCRETE STRUCTURE IN GERMAN NOVEL
}

\author{
CARACTERÍSTICAS ARTÍSTICAS DE ESTRUTURA DISCRETA EM ROMANCE \\ ALEMÃO
}

\author{
CARACTERÍSTICAS ARTÍSTICAS DE LA ESTRUCTURA DISCRETA EN EL \\ ROMANCE ALEMÁN
}

\author{
Alfiia Revanerovna VALEEVA ${ }^{1}$ \\ Gulnara Tavkilevna GILFANOVA ${ }^{2}$ \\ Elena Alexandrovna NIKULINA ${ }^{3}$
}

\begin{abstract}
The article deals with the key stages of the formation and development of German fragmentary prose in the 19th-20th centuries. Using the materials from German novels of the 20th century, the authors analyze the artistic devices that motivate the discreteness of the narrative and determine their artistic function - the manifestation and structuring of aesthetic information. Based on the analysis of artistic devices, the aesthetic content of the discrete novel structure is identified, which depends on the writers' worldview. The discrete structure has proven to be a universal art form that has shaped the typological features of the modern novel.
\end{abstract}

KEYWORDS: Fragmentary prose. Discrete structure. Montage principle. Multiperspectivity. Issue of time and memory.

RESUMO: $O$ artigo trata das principais etapas da formação e desenvolvimento da prosa fragmentária alemã nos séculos 19-20. Usando os materiais dos romances alemães do século $X X$, os autores analisam os dispositivos artísticos que motivam a discrição da narrativa e determinam sua função artística - a manifestação e estruturação da informação estética. Com base na análise dos dispositivos artísticos, é identificado o conteúdo estético da discreta estrutura da novela, que depende da visão de mundo dos escritores. A estrutura discreta provou ser uma forma de arte universal que moldou as características tipológicas do romance moderno.

PALAVRAS-CHAVE: Prosa fragmentária. Estrutura discreta. Princípio de montagem. Multiperspectividade. Questão de tempo e memória.

RESUMEN: El artículo aborda las principales etapas de la formación y el desarrollo de la prosa fragmentaria alemana en los siglos XIX y XX. Utilizando los materiales de obras

1 Naberezhnye Chelny State Pedagogical University (NCSPU), Naberezhnye Chelny - Russia. ORCID: https://orcid.org/0000-0001-7381-7650.E-mail: vale.alfiya@yandex.ru

${ }^{2}$ Kazan Federal University (KPFU), Naberezhnye Chelny - Russia. ORCID: https://orcid.org/0000-0002-81736268. E-mail: gilfanova.g.t@mail.ru

${ }^{3}$ Moscow Pedagogical State University (MPGU), Moscow - Russia. ORCID: https://orcid.org/0000-0002-12698720. E-mail: nikulina.e.a@bk.ru 
novelescas alemanas del siglo XX, los autores analizan los dispositivos artísticos que motivan la discreción de la narración y determinan su función artística: la manifestación y estructuración de la información estética. A partir del análisis de los dispositivos artísticos, se identifica el contenido estético de la estructura discreta de la novela, que depende de la visión del mundo de los escritores. La estructura discreta resultó ser una forma de arte universal que configuró los rasgos tipológicos de la novela moderna.

PALABRAS CLAVE: Prosa fragmentaria. Estructura discreta. Principio de montaje. Multiperspectividad. Cuestión de tiempo y memoria.

\section{Introduction}

In the research into the modern novel, the concepts of "fragmentary prose" (TARNARUTSKAYA, 2012) and "nonlinear prose" (SPIRIDONOV, 2009) are used, denoting the narrative manner of modern writers. Its main feature is fragmentation (discreteness) of artistic narration.

The unit of the artistic structure in a work that belongs to fragmentary prose is defined by the term "fragment" in contemporary Russian literary studies. The term "fragment" is also used to refer to an independent genre. According to V.I. Greshnykh, a fragment, the genre history of which dates back to ancient literature (dictum, aphorism, maxim, paradox, dialogue) was formed as a genre at the end of the $18^{\text {th }}$ century (GRESHNYKH, 1991).

The fragment is characterized by openness and dynamism. As a component, the fragment penetrates the established genre structures, on the one hand, destroying them and, on the other hand, returning literature to its original forms, to artistic syncretism (GRESHNYKH, 1991).

The artistic feature of a fragment as a structural unit is that being an unfinished passage, the fragment reflects the striving of the structure of the novel towards integrity and reveals the process of artistic interpretation of reality.

The concept of discreteness is widely used in various fields of science, including philology. For example, the linguist I.R. Galperin notes that the discreteness of a separate part "aims to highlight the actualized, make the reader pay attention to a part of the general movement and see the place of this part within the continuous flow of information" (GALPERIN, 1981). In modern text linguistics, discreteness is considered a typological category associated with the category of integrity, the most significant for characterizing the structure (ICHKINEEVA, 2009). 
Literary scholar B.M. Gasparov writes about the features of the discrete structure of a literary text:

The text acts [...] as a structure built of discrete components, in a certain way correlated with each other and forming a hierarchy, - and as an indivisible conglomerate, a kind of semantic 'plasma' in which many different components, general and particular, explicit and implicit, linear and nonlinear, are dissolved in each other and manifest only through fusion with the other components (GASPAROV, 1993).

In the article, we use the terms "fragmentary prose" as a definition for the manner of narration that is already well-established in literary studies and "discrete structure" (VALEEVA, 1994) to characterize the artistic structure of a novel.

The genre of the novel is traditionally considered the most dynamic, constantly developing literary genre and arouses the keen interest of philologists. The fundamental works of literary scholars are devoted to the research of the genre: "The Art of Novel and the 20th century" by D.V. Zatonsky (1973), "Novel as a free form" by T.L. Motyleva (1982), "The poetics of the novel" by N.T. Rymar (1990), "The typology of the novel" by A.Ya. Elsanek (1991), and "Modifications of the novelistic form in the Western prose of the second half of the 20th century" by V.A. Pesterev (1999).

The most notable theoretical works on the German novel of the $20^{\text {th }}$ century include "The German novel in 1918-1945" by N.S. Leites (1975), "Typology of the German novel from 1900 to 1945 " by N.S. Pavlova (1982), "Typology of the GDR novel" by I.V. Mlechina (1985), "The German-language novel in the 1980s-2000s: the focus on demythologization" by G.V. Kuchumova (2009), and "German literature of the 1990s: the turning point" by D.A. Chugunov (2019).

The typological features of the novel genre, including structural features, are examined in numerous studies devoted to the work of German writers - A. Döblin (DRONOVA, 2015), J. Bobrowski (FROLOV; GILFANOVA, 2019), K. Volf (GUROV, 1993), Ch. Hein (VALEEVA, 1994), and others.

All studies point to the steady trend of the increasing complexity of the novel structure. We believe that, despite the numerous works on the genre features of the novel, individual works on the structure of the literary text (Lotman, 1970), and novels by German writers, the issue of the artistic features of the discrete novel structure remains insufficiently studied. 


\section{Materials and methods}

The subject of the study is the structural features of German novels of the $20^{\text {th }}$ century.

The research methodology is based on literary and cultural approaches to literary phenomena. Cultural-historical, comparative-typological, and hermeneutic methods became the methodological basis of the research. Moreover, we used a system analysis technique.

The cultural-historical method involved the inclusion of the object of research in the global general cultural context.

The comparative typological method was used to study the genre characteristics of works, as well as the issues of innovation and tradition in literature.

The hermeneutic method was associated with the interpretation of a literary text.

In the study of the art form of novels, the method of system analysis was used.

\section{Results}

The emergence of fragmentary prose is associated with the aesthetics of romanticism and the emergence of the fragment genre. A significant contribution to the further development of fragmentary prose was made by modernist and postmodern literary movements in the $20^{\text {th }}$ century.

Groundbreaking changes in the narrative technique of the turn of the century have become traditional artistic techniques that simulate the discrete structure and typological features of the $20^{\text {th }}$-century novel.

Writers' widespread use of a variety of artistic techniques that form the fragmentation of the narrative and the discrete structure of the novel creates a dynamic artistic environment. The structure of the modern German novel is characterized by multidimensionality, dialogicality, and meaningfulness.

\section{Discussion}

The discrete structure of the novel as a literary phenomenon is one of the characteristic structural trends that are indicative of $20^{\text {th }}$-century literature. At the same time, discreteness cannot be attributed only to the artistic features of the $20^{\text {th }}$ century. This artistic structure has its deep roots and origins, dating back to $19^{\text {th }}$-century literature. 


\section{Fragmentary prose of the $19^{\text {th }}$ century}

According to researchers V.I. Greshnykh and F.P. Fedorov, the emergence of fragmentary prose is associated with the aesthetics and artistic practice of German romanticism (GRESHNYKH, 1991; FEDOROV, 1988). It is in the culture of romanticism that a new fragmentary type of artistic thinking was established (GRESHNYKH, 1991). The poetics of fragmentation was fruitfully developed by F. Schlegel and Novalis, whose "Fragments" were a declaration of romantic aesthetics.

Influenced by romantic aesthetics and a fragmentary style of thinking, a romantic novel structure was created, which is a series of interacting fragments edited together (FEDOROV, 1988). For example, "Lucinde" by F. Schlegel and "Countess Dolores" by L. von Arnim are structured as a series of chapter-fragments, as "chaos" and "romantic confusion".

The structure of the classic genre of the novel was characterized by a chronologically linear narrative and a causal relationship between episodes. The inclusion of fragments in the novel structure had occurred earlier in the literature of the Middle Ages and the Renaissance. Despite the relative independence of heterogeneous narrative elements, the integrity of the work was not disrupted.

Romanticism violated the canonicity of the novel genre in the interpretation of the issues of space and time and led to the emergence of a discrete structure. This structure manifested itself in $19^{\text {th }}$-century literary works in the discrepancy between the chronological sequence of events and their literary presentation, with the plot and compositional order of changing the components of the work (IVANOV, 1974).

Further development of fragmentary prose is associated with the literary trends of the late $19^{\text {th }}$ century. Discreteness of the worldview and the way of artistic reproduction of reality reflects, for example, the use of the impressionistic method of spontaneity.

\section{Fragmentary prose of the $20^{\text {th }}$ century}

In both science and art of the $20^{\text {th }}$ century, one of the main problems is the relationship between the continuous and the discrete. A discrete type of thinking dominates in culture, reflecting the mismatch between human perception of time and its real course.

According to V.A. Pesterev, "in the $20^{\text {th }}$ century, a fragmentary form as a reinterpretation that does not exclude rejection of the genre traditions of the novel, is multidirectionally avant-garde" (PESTEREV, 2004) and "reveals unique" and "revolutionary" 
discoveries in a verbal and artistic form" (PESTEREV, 1999). One of these discoveries was the way of depicting an individual vision of the world, which, starting with M. Proust and J. Joyce, motivated the discreteness of the worldview by the structure of the stream of consciousness (IVANOV, 1974). The discrete form as a way of the aesthetic depiction of reality became a universal art form of the $20^{\text {th }}$ century.

In German literature of the early $20^{\text {th }}$ century, fragmentation and structural discontinuity are characteristic of the works of expressionists, which were structured as a rapid change of contrasting scenes and frames. The artistic achievement of the expressionists was "the method of combining far-apart moments that created a feeling of correlation and simultaneity of various processes taking place in the world" (PAVLOVA, 1962).

The principle of montage became widespread in the literature of the "new objectivism" which implied the inclusion of fragments with different genre design in the novel structure: newspaper articles, advertising slogans, announcements, minutes. Fragments of other styles activated the reader's creative abilities, immersing them in the artistic world closely connected with reality.

Evaluating the development of the literary process in the second half of the $20^{\text {th }}$ century from the perspective of new artistic discoveries, one should note the general tendency towards the synthesis of arts and the postmodern tendency towards form creation. However, according to Pesterev (1999), "the novelist of the second half of the century not so much discovers as improves, develops thoroughly, modifies techniques and creates innovations in artistic structures".

\section{The montage principle}

Montage as a compositional principle was used earlier in the literature of the $19^{\text {th }}$ century but the literature of the $20^{\text {th }}$ century had a particular focus on montage, which is partly due to the influence of cinema that arose at the turn of the century.

The essence of montage is that separate, fairly independent units of text (fragments) which can be of different genres and styles are collected into a single whole. As a result of the montage of artistic fragments of text and fragments of different styles, a dynamic change in image scales and points of view, a cinematic participation effect arises aimed to objectify the depicted and create a "dynamic observation effect" (MARTYANOVA, 2001). 
By the end of the $20^{\text {th }}$ century, the interaction and mutual influence of literature and cinema are considered already from the standpoint of the synthesis of arts. This allows us to speak of cinematic depiction as a characteristic feature of modern fragmentary prose.

Let us consider the structural changes that have emerged in the development of the novel genre. We consider the example of the montage principle application in German literary works of the 20th century, different both in the type of creativity and in the time of creation: H. Mann's dilogy "Die Jugend und die Vollendung des Königs Henri Quatre" (MANN, 1978) and the novels "Berlin Alexanderplatz" by Döblin (1961) and "Kindheitsmuster" by Wolf (1976).

Throughout the novel "Berlin Alexanderplatz" which is about the life of F. Biberkopf, there is a constant movement and shift of perspectives and frames from the stream of consciousness of the author and the characters. The subjective and the objective alternate and collide. Various fragments of reality snatched from different eras and different spheres are connected.

The historical dilogy "Die Jugend und die Vollendung des Königs Henri Quatre" by Mann, just like Döblin's novel, is permeated with movement. The plot is built as a swift series of rapidly changing scenes and episodes. However, unlike Döblin, Mann does not strive for the breadth of coverage of reality. The author's attention is focused on the main character and the manifestations of the character's personality in constantly changing situations.

In "Kindheitsmuster" by Wolf, there is no single coherent plot similar to the plot of "Berlin Alexanderplatz" or "Die Jugend und die Vollendung des Königs Henri Quatre". The action simultaneously unfolds in different temporal and plot planes. Three narrative tenses are combined and intertwined. The novel is structured as a montage of episodes from the life of the girl Nelly Jordan and the history of the Third Reich, fragments of the story about the writer's trip to the city of the girl's childhood, and reflections on current events.

The novels by Mann, Döblin, and Wolf are different in their structure but similar in the principle of episode montage. Different montage pieces contain the same higher meaning, the idea of the whole work. For Döblin, the main idea is human involvement in the iron mechanism of the universe, the study of one internal theme - whether a person can resist the world (PAVLOVA, 1982). Mann's main task is to reveal the hidden essence of social phenomena, the type of a person's reaction to social reality (PAVLOVA, 1982). The subject of Wolf's analysis is the question of the degree of an individual's civil responsibility for what is happening. Thus, fragmentation in the novels by Mann, Döblin, and Wolf is a deliberate narrative technique, and the discrete structure is conceptual. 


\section{The issue of time and memory as a structural principle}

A characteristic feature of $20^{\text {th }}$-century literature was the appeal to the issue of time and memory as a structural principle of constructing works. As a result, the novel becomes reflective, retrospective. The issue of memory and time as a structural principle determined the compositional organization of such novels as "Preisverleihung" by De Bruyn (1982), "Der fremde Freund" by Hein (1982), and "Deutschstunde" by Lenz (1971). When comparing the artistic organization of these novels, similarities are evident. Recollection and reflection which underlie the narrative destroy the chronological sequence of actions and the causal relationships of the narrative elements.

Thus, the structure of the novel "Deutschstunde" by Lenz, the protagonist of which writes down memories, determines the desire to comprehend the events of the past. In the novel, the time of the story and the time of narration, the past and the present are combined. The temporal and psychological distance changes. Many stories and their interpretation by the main character and other people are edited.

The structure of the novel "Preisverleihung" by De Bruyn, the events of which cover one day in the life of the character preparing to make a speech and recalling his past years, also connects the past and the present, the time of remembrance and the time of action, real events and reflection.

"Der fremde Freund" by Hein, like the novels by Lenz and De Bruyn, has a retrospective nature and is a confession of the female character who is trying to remember the story of her acquaintance with her recently deceased friend. The chronicle of meeting the friend is interspersed with events from the present time and events from the character's childhood.

Typological structural similarity of the novels by Lenz, De Bruyn, and Hein lies in the fact that the montage of a fragmentary plot is carried out according to the principle of associative-logical connection. The association, and not the actions of the character or any external reasons, become the driving force of the plot.

The evolution of the discrete structure of the 20th-century novel has shown that the associative-logical connection of fragments can be motivated not only by the stream of consciousness or memory but also by other associative discrete models. Artistic material can be organized as a nesting doll (in a spiral) (ASANOVA; SMIRNOV, 1997), dictionary, puzzle games (PESTEREV, 1999), encyclopedia, or labyrinth (SPIRIDONOV, 2009). 


\section{Multiperspectivity}

In $20^{\text {th }}$-century literature, there was a change in the narrator's role, status, function, and the narrative perspective, which in turn caused significant structural changes. Thus, in the compositional organization of the novel, the multiperspectivity technique began to be widely used - the introduction of parallel narratives about the same events from the different characters' perspectives, a constant change in the point of view and narrative distance.

As an example, let us examine the use of the artistic approach of multiperspectivity in the novels "Billiards at Half-past Nine" by Böll (1965), "The D'Arthez Case" by Nossack (1983), and "Horns Ende" by Hein (1985).

"Billiards at Half-past Nine" is a novel with third-person narration that includes memories and inner monologues of the Fähmel family members taking turns acting as storytellers. The events passed through the perception of the characters are simultaneously illuminated by the narrator.

The novel "Horns Ende" by Hein also has a discrete structure and represents the fragmentary memories of the five residents of the town about themselves, city events, and Horn the museum director. As a result of the interaction of fragments in the novels by Böll and Hein, a clash of different points of view arises, allowing recreating a reliable and multidimensional picture of reality.

If Böll and Hein strive for utmost objectivity, the narrative in the novel "The D'Arthez Case" by Nossack gives the impression of fragility and uncertainty. Nossak's novel is structured as an interweaving of monologues by different characters, the narration of a certain storyteller - a "minute maker" who reports information about D'Arthez from many sources and constantly stipulates their hypotheticalness. Moreover, from time to time the "minute maker" begins to talk about himself in the third person. This mobility of points of view, none of which can be called absolute, gives rise to a feeling of uncertainty and detachment from reality.

Comparative analysis of novels by Böll, Hein, and H.E. Nossack showed that the use of multiperspectivity is a structural method of the aesthetic depiction of reality that models the artistic meaning of a work.

\section{Conclusion}

Fragmentary prose arose in the era of romanticism as a result of the rejection of the artistic experience of the Enlightenment as a new way of artistic depiction of reality. The 
same reasons - the rejection of the $19^{\text {th }}$-century artistic traditions including the genre traditions of the novel, determined the aesthetic transformations in the literature of the early $20^{\text {th }}$ century. Aesthetic searches were revolutionary and multidirectional, but in the course of the development of the $20^{\text {th }}$-century literary process, new methods lost their status, becoming traditional artistic techniques. The development of the novel in the second half of the $20^{\text {th }}$ century was largely aimed at the artistic synthesis of the "traditional" and the "non-genre", the improvement and modification of artistic techniques.

Artistic techniques that appeared in $20^{\text {th }}$-century literature motivate, form, and even visualize the discreteness of the narrative, the main artistic function of which is to represent aesthetic information that depends on the novelist's artistic worldview.

The use of multiperspectivity and the montage principle, the appeal to the problem of time and memory as a structural principle reflect the general trend in the development of the 20th-century novel - the complication of the structure, the increase in its dynamism, and intellectual meaningfulness.

The discrete structure becomes the basis of artistic narration in the $20^{\text {th }}$-century German novel and determines the characteristic features of the novel genre: the rejection of chronological sequence, mixing of temporal layers, weakening of the interconnection of external events, multiple subjects, switching of narrative perspective.

The discrete structure has proven to be a universal art form that allows representatives of various literary trends to use its typological characteristics such as flexibility, dialogicality, and meaningfulness to form aesthetically different artistic meanings.

\section{REFERENCES}

ASANOVA, N. A.; SMIRNOV, A. S. Filosofskii roman Mishelya Turne [Michel Tournier's philosophic novel]. Kazan: Izdatelstvo Kazanskogo universiteta, 1997.

BÖLL, H. Bilyard v polovine desyatogo [Billiards at Half-Past Nine]. Moscow: Mir, 1965.

CHUGUNOV, D. A. Nemetskaya literatura 1990-kh godov: situatsiya "povorota" [German literature of the 1990s: the turning point]. Moscow: Infra-M, 2019.

DE BRUYN, G. Selected works. Moscow: Progress, 1982.

DÖBLIN, A. Berlin alexanderplatz. Moscow: Goslitizdat, 1961.

DRONOVA, O. A. Romany "novoi delovitosti" v kontekste literaturnoi kinematografichnosti [Novels of "new objectivism" within the context of cinematographic writing]. Vestnik Permskogo universiteta. Rossiiskaya i zarubezhnaya filologiya, v. 3, n. 31, p. 88-94, 2015. 
ELSANEK, A. Y. Tipologiya romana [The typology of the novel]. Moscow: Izdatelstvo MGU, 1991.

FEDOROV, F. P. Romanticheskii khudozhestvennyi mir: prostranstvo i vremya [The romantic world of fiction: space and time]. Riga: Zinatne, 1988.

FROLOV, G.A., GILFANOVA, G.T. Retseptsiya i rekonstruktsiya khudozhestvennogo opyta I. Bobrovskogo v poslevoennoi nemetskoi literature (1950-1970-e gg.) [Reception and Reconstruction of J. Bobrowski's Artistic Experience in the Post-War German Literature (the 1950-1970s)]. Filologicheskie nauki. Voprosy teorii i praktiki, v. 12, n. 4, p. 407-411, 2019.

GALPERIN, I. R. Tekst kak obekt lingvisticheskogo issledovaniya [Text as an object of linguistic research]. Moscow: Nauka, 1981.

GASPAROV, B. M. Literaturnye leitmotivy. Ocherki po russkoi literature XX veka [Literary leitmotifs. Essays on Russian literature of the 20th century]. Moscow: Nauka, 1993.

GRESHNYKH, V. I. Rannii nemetskii romantizm: fragmentarnyi stil myshleniya [Early German romanticism: fragmentary thinking]. Leningrad: Izdatelstvo LGU, 1991.

GUROV, P. A. Istoriya i sovremennost $\mathbf{v}$ khudozhestvennoi i esseisticheskoi proze Kristy Volf 70-kh - 80-kh godov [History and modernity in fiction and essays by Christa Wolf in the 1970s-1980s]: Abstract of Dissertation by the Candidate of Philological Sciences. Moscow, 1993.

HEIN, C. H. Der fremde freund. Berlin, Weimar: Aufbau-Verlag, 1982.

HEIN, C H. Horns ende. Berlin: Aufbau-Verlag, 1985.

ICHKINEEVA, D. A. Distantnye i kontaktnye svyazi kak sposob realizatsii kategorii diskretnosti i kontinualnosti struktury teksta [Distance and contact connections as a way of implementing the category of discreteness in the continuality of the text structure]. Vestnik Chelyabinskogo gosudarstvennogo universiteta, v. 39, p. 53-57, 2009.

IVANOV, V. V. Kategoriya vremeni $\mathbf{v}$ iskusstve i kulture $\mathbf{X X}$ veka [The category of time in the art and culture of the 20th century]. Ritm, prostranstvo $i$ vremya $v$ literature $i$ iskusstve [Rhythm, space and time in literature and art]. Leningrad: Nauka, 1974.

KUCHUMOVA, G. V. Nemetskoyazychnyi roman 1980-2000 gg.: kurs na demifologizatsiyu [The German-language novel in the 1980s-2000s: the focus on demythologization]. Samara: Samarskaya gumanitarnaya akademiya, 2009.

LEITES, N. S. Nemetskii roman 1918-1945. Evolyutsiya zhanra [The German novel in the 1918-1945. The evolution of the genre]. Perm: Izdatelstvo PGU, 1975.

LENZ, S. Deutschstunde. Moscow: Progress, 1971.

LOTMAN, Y. M. Struktura khudozhestvennogo teksta [The structure of the artistic text]. Moscow: Iskusstvo, 1970. 
MANN, H. Die Jugend des Königs Henri Quatre. Moscow: Khudozhestvennaya literatura, 1978.

MARTYANOVA, I. A. Kinovek russkogo teksta: Paradoks russkoi kinematografichnosti [Cinema century of the Russian text: the paradox of literary cinematography]. Saint Petersburg: SAGA. 2001.

MLECHINA, I. V. Tipologiya romana GDR [Typology of the GDR novel]. Moscow: Nauka, 1985.

MOTYLEVA, T. L. Roman: svobodnaya forma [Novel as a free form]. Moscow: Sovetskii pisatel, 1982.

NOSSACK, H. E. Izbrannoe [Selected works]. Moscow: Raduga, 1983.

PAVLOVA, N. S. Ekspressionizm i nekotorye voprosy stanovleniya sotsialisticheskogo realizma $\mathrm{v}$ nemetskoi demokraticheskoi literature [Expressionism and the formation of socialist realism in German democratic literature]. Realizm i ego sootnosheniya s drugimi tvorcheskimi metodami [Realism and its relation to other creative methods]. Moscow: Izdatelstvo AN SSSR, 1962.

PAVLOVA, N. S. Tipologiya nemetskogo romana 1900-1945 [Typology of the German novel from 1900 to 1945]. Moscow: Nauka, 1982.

PESTEREV, V. A. Modifikatsii romannoi formy v proze Zapada vtoroi poloviny XX stoletiya [Modifications of the novelistic form in the Western prose of the second half of the 20th century]. Volgograd: Izdatelstvo Volgogradskogo gosudarstvennogo universiteta, 1999.

PESTEREV, V.A. Fragmentarnaya forma romana Zh.-F. Tussena "Fotoapparat" [Fragmentary form of Jean-Philippe Toussaint's novel "L'Appareil-photo"]. Baltiiskii filologicheskii kurer, v. 4, p. 285-305, 2004.

RYMAR, N. T. Poetika romana [The poetics of the novel]. Saratov: Izdatelstvo Saratovskogo universiteta, 1990.

SPIRIDONOV, D. V. Estetika istorizma i poetika nelineinogo pis'ma v evropeiskoi literature kontsa KhKh veka [Aesthetics of Historicism and Non-Linear Narrative Poetics in the Late 20th Century European Literature]: Abstract of Dissertation by the Candidate of Philological Sciences. Ekaterinburg, 2009.

TARNARUTSKAYA, E. V. Problema narrativnosti vo fragmentarnoi proze (na materiale literatury XX veka) [Narrativity in fragmentary prose (case study of 20th century literature]: Abstract of Dissertation by the Candidate of Philological Sciences. Samara, 2012.

VALEEVA, A. R. Romany Kristofa Khaina [Christoph Hein's novels]: Abstract of Dissertation by the Candidate of Philological Sciences. Nizhny Novgorod, 1994. 
VALEEVA, A. R.; KAGUI, N. V. Prostranstvo i vremya v romane "Smert Khorna" Kristofa Khaina [Space and time in Ch. Hein's novel "Horns Ende"]. Sovremennye issledovaniya sotsialnykh problem [Modern research of social issues], v. 10, n. 4-2, p. 39-45, 2018.

WOLF, C. H. Kindheitsmuster. Berlin: Aufbau-Verlag, 1976.

ZATONSKY, D. V. Iskusstvo romana i XX vek [The Art of Novel and the 20th century]. Moscow: Khudozhestvennaya literatura, 1973.

\section{How to reference this article}

VAlEEVA, A. R.; GILFANOVA, G. T.; NIKULINA, E. A. Artistic features of discrete structure in german novel. Rev. EntreLínguas, Araraquara, v. 7, n. esp. 2, e021016, 2021. eISSN: 2447-3529. DOI: https://doi.org/10.29051/el.v7iesp.2.15142

Submitted: 05/01/2021

Required revisions: $26 / 02 / 2021$

Approved: 24/03/2021

Published: 01/06/2021 